\title{
Introduction to the Special Issue: The multiple births of International Relations
}

\author{
Vineet Thakur ${ }^{1 \star}$ (D) and Karen Smith ${ }^{2}$ \\ ${ }^{1}$ Institute for History, Leiden University, Leiden, The Netherlands and ${ }^{2}$ International Relations, Leiden University and \\ University of Cape Town \\ *Corresponding author. Email: v.thakur@hum.leidenuniv.nl
}

(Received 2 March 2021; revised 18 June 2021; accepted 9 August 2021; first published online 24 September 2021)

\begin{abstract}
Disciplinary histories are, by default, complicit in the production of subjective memories as truth. This Special Issue builds on the existing scholarship on rethinking IR's disciplinary history by expanding its geographical focus beyond the West, and explores how IR came to define itself as a self-contained body of knowledge that is distinct from other fields of study in different parts of the world. These alternative histories enable us to appreciate that the development of IR as a global discipline was only possible through a transnational circulation of key ideas such as sovereignty, empire, Commonwealth and, especially, competing notions of the 'international'. In addition, they bring attention to the purpose of knowledge and the politics of its production, and allow for both democratisation as well as discursive plurality.
\end{abstract}

Keywords: IR Origins; Post-Western IR; Disciplinary Histories; Global South

\section{Introduction}

In 1932, a recent London-returnee to India, Lanka Sundaram, wrote a letter to the secretary of the Royal Institute of International Affairs (RIIA), Ivison S. Macadam. Sundaram had recently become the first Indian to publish an academic article in the Institute's official journal, The Journal of the Royal Institute of International Affairs (today's International Affairs). ${ }^{1}$ A doctor in international law, Sundaram had also spent considerable time in the Chatham House library, and was quite well versed with the rituals and objectives of research at the Institute. Aware that it was looking to open affiliates in other parts of the 'Commonwealth' - a term preferred over 'Empire' at the Institute - Sundaram informed Macadam that he had recently started 'The Indian Institute of International Affairs' in Bezwada (Viajayawada), and 'considering the poverty and general unpreparedness of India', requested the RIIA to provide affiliation and subsidy to his initiative. His aim, initially, was to start a library on international affairs in India and thus quicken Indian interest in extra-territorial matters'. ${ }^{2}$ This seemingly benign request was received with alarm at the RIIA. Instead of writing to Sundaram, Macadam first wrote to the Imperial Government's India Office enquiring about Sundaram. The Madras intelligence department was eventually roped in to report on Sundaram, and warned about his pro-Indian National Congress sympathies and bitter hostility towards the policy of the British Indian government.

\footnotetext{
${ }^{1}$ Lanka Sundaram, 'The international status of India', Journal of the Royal Institute of International Affairs, 9:4 (1930), pp. 452-66.

${ }^{2}$ British Library, London, India Office and Records, IOR/L/I/1/427, 'Lanka Sundaram to I. Macadam', 20 September 1932.

(C) The Author(s), 2021. Published by Cambridge University Press on behalf of the British International Studies Association. This is an Open Access article, distributed under the terms of the Creative Commons Attribution licence (http://creativecommons.org/licenses/by/4.0/), which permits unrestricted re-use, distribution, and reproduction in any medium, provided the original work is properly cited.
} 
With the eye of suspicion firmly cast on Sundaram's politics, the RIIA declined to provide him any support. ${ }^{3}$

The archival footprints of Sundaram's next move are blurry. In 1933, he still published alongside Alfred Zimmern and Charles Manning in a book on India and his short bio read 'Director, The Indian Institute of International Affairs'. ${ }^{4}$ But more interestingly, soon thereafter, in March 1936, the RIIA opened its own affiliate in India. It was also called 'The Indian Institute of International Affairs' (IIIA), conveniently plagiarising and erasing from history in one stroke any titular claims of Sundaram's institute. The new Institute was packed with not only progovernment politicians, but also several serving civil servants in the British Indian government. With little concern for subtleties, the first meeting of the new Institute was held in the house of the viceroy - an imposing 340-room mansion spread over five acres on a 330-acre estate, lording over the recently built national capital, New Delhi. The birth of this International Relations (IR) institute happened at the very epicentre of a colonial empire, contrived through the erasure of another.

The story, however, takes another turn. In the 1940s, as colonialism in India ran out of steam with Indian independence looking well in sight, a few members of the IIIA rebelled to form a separate institute. The new institute, the Indian Council for World Affairs (ICWA), aligned itself closely with the Indian National Congress but claimed objectivity, while decrying its parent for being extremely political - meaning colonial and pro-Muslim. On the eve of independence, after a bitter contest for legitimacy between the two institutes, the IIIA was physically transported from the Indian capital of Delhi to the new capital of Pakistan, Karachi. Consequently, the two premier IR institutes in the subcontinent - the ICWA and the Pakistan Institute for International Affairs continue to misremember their own origins. The ICWA has erased the IIIA from its institutional memory, while the Pakistan Institute for International Affairs calls itself the successor of the colonial 'Indian' IIA. ${ }^{5}$

This story illustrates a number of issues with regard to the nature of 'origin' stories that this Special Issue intends to raise. First, there are at least three 'origin' stories of Indian IR - of Sundaram's IIIA, of the Chatham House-backed IIIA, and of the ICWA. While in the discussion below we will illustrate why origin stories are important, this illustration alerts us to the tendentious character, if not the fickleness, of such stories. They are often deliberately contrived to uphold one claim over history - and consequently the future - over others. Second, this speaks to the question of who was (and perhaps still is) deemed to be qualified to study International Relations. In colonial India, for instance, maintaining imperial control over investigations into questions of international affairs was deemed essential to maintaining political control. ${ }^{6}$ Third, each of the three origin stories above comes with their own politics, and indeed understandings of the role of 'politics' in knowledge production. While Sundaram's institute was disallowed because it was suspected that it could have pro-Congress sympathies, the RIIA-backed Indian Institute was not only allowed but promoted precisely because it was pro-government in its sympathies and orientation. The assumption that only those with anti-colonial sympathies had politics while those with pro-government sympathies did not was rooted in particular understandings of scientific objectivity that emerged from the RIIA.

Certainly, all modern social science disciplines have framed their claims to legitimacy around their divorce from subjective reasoning and a fastened adherence to scientific objectivity. In this,

\footnotetext{
${ }^{3}$ IOR/L/I/1/427, 'I. Macadam to R. A. Butler', 9 November 1932, p. 21; IOR/L/I/1/427, 'Confidential - Public Department, D.O. No. 823-S', 14 December 1932, p. 14.

${ }^{4}$ See Alfred Zimmern, C. A. W. Manning, and Lanka Sundaram, India Analysed (London, UK: Victor Gollangz, 1933). Sundaram would later go on to have a successful parliamentary career in independent India.

${ }^{5}$ See Vineet Thakur and Alexander E. Davis, 'A communal affair over international affairs: The arrival of IR in late Colonial India', South Asia: Journal of South Asian Studies, 40:4 (2017), pp. 689-705.

${ }^{6}$ Nicholas Guilot, 'Imperial realism: Post-war IR theory and decolonisation', The International History Review, 36:4 (2014), pp. $698-720$.
} 
International Relations is no different. But perhaps none has made the claim quite with the latter's moral certitude. The foundational lore of IR is that the key to solving the problems of the interwar era, mostly the problem of war, was to study international relations objectively and scientifically. The First World War was assumed to be caused by partisan politicians; permanent peace could only be orchestrated by scientific expertise. Presumably, the study of international 'politics' could only be objective if it extricated the second word from its own 'body politic'. In line with this, the RIIA explicitly committed itself to a non-political, non-partisan agenda. In a colonial setting, however, only a colonial bureaucrat or progovernment sympathiser could be a 'scientific expert', capable of producing knowledge on international relations; the anti-colonial intellectual was merely a 'political' partisan.

\section{Multiple births, multiple histories: Framing questions}

The erasure of certain issues, stories, and voices, and the promotion of others has become a focus in the recent calls for a post-Western International Relations (IR). An important element of these calls has to do with recognising the agency of non-Western actors in not only responding to Western incarnations of the field and its accompanying theories, but actively shaping it. This includes rethinking IR's disciplinary history, of which there now exists a flourishing scholarship that interrogates the contested 'birth' and development of IR. ${ }^{7}$ In particular, the imperial, gendered, and racist origins of the discipline have been highlighted. While intending to contribute to this emerging body of literature, we also seek to expand its geographic focus. Work by, among others, Vineet Thakur and Peter Vale, ${ }^{8}$ has shown that there is still a dearth of knowledge about how IR developed in the non-Western world. The discussions about IR's origins are still primarily limited to the West, and consequently, even critical histories of the discipline tend to reinforce the centrality of issues that are formative but also at times limited to Western experiences. A very specifically American understanding of racial politics, for instance, as Robert Vitalis's work has shown, ${ }^{9}$ is at the very core of any American disciplinary gaze into the world. But is that also true of places such as China, or Ghana, or Brazil, or Korea, or even

\footnotetext{
${ }^{7}$ Duncan Bell, 'International Relations: The dawn of a historiographical turn?', British Journal of Politics and International Relations, 3:1 (2001), pp. 115-26; Gerard Holden, 'Who contextualizes the contextualizers? Disciplinary history and the discourse about IR discourse', Review of International Studies, 28:2 (2002), pp. 253-70; Brian C. Schmidt, The Political Discourse of Anarchy: A Disciplinary History of International Relations (Albany, NY: State University of New York Press, 1998); Torbjørn L. Knutsen, 'A lost generation? IR scholarship before World War I', International Politics, 45:6 (2008), pp. 650-74; Nicolas Guilhot, After the Enlightenment: Political Realism and International Relations in the Mid-Twentieth Century (Cambridge, UK: Cambridge University Press, 2017); Nicolas Guilhot, The Invention of International Relations Theory: Realism, the Rockefeller Foundation, and the 1954 Conference on Theory (New York, NY: Columbia University Press, 2011); Robert Vitalis, White World Order, Black Power Politics: The Birth of American International Relations (Ithaca, NY: Cornell University Press, 2015); Ido Oren, Our Enemies and US: America's Rivalries and the Making of Political Science (Ithaca, NY and London, UK: Cornell University Press, 2003); David Long and Brian C. Schmidt (eds), Imperialism and Internationalism in the Discipline of International Relations (Albany, NY: State University of New York Press, 2005); Patricia Owens, 'Women and the history of international thought', International Studies Quarterly, 62:3 (2018), pp. 467-81; Patricia Owens and Katharina Rietzler (eds), Women's International Thought: A New History (Cambridge, UK: Cambridge University Press, 2021); Lucian Ashworth, A History of International Thought: From the Origins of the Modern State to Academic International Relations (London, UK: Routledge, 2014); Siba Grovogui, Beyond Eurocentrism and Anarchy: Memories and International Order and Institutions (Basingstoke, UK: Palgrave Macmillan, 2006); Felix Rösch (ed.), Émigré Scholars and the Genesis of International Relations: A European Discipline in America? (Basingstoke, UK: Palgrave Macmillan, 2014); Or Rosenboim, The Emergence of Globalism: Visions of World Order in Britain and the United States, 1939-1950 (Princeton, NJ: Princeton University Press, 2017); Vineet Thakur and Peter Vale, South Africa, Race and the Making of International Relations (London, UK: Rowman and Littlefield, 2020); Amitav Acharya and Barry Buzan, The Making of Global International Relations: Origins and Evolution of IR at its Centenary (Cambridge, UK: Cambridge University Press, 2019); Jan Stöckmann, 'Studying the international, serving the nation: The origins of International Relations (IR) scholarship in Germany, 1912-33', The International History Review, 38:5 (2016), pp. 1055-80.

${ }^{8}$ See, for example, Vineet Thakur and Peter Vale, 'Empty neighbourhood: Race and disciplinary silence', in Jenny Edkins (ed.), Routledge Handbook of Critical International Relations (London, UK and New York, NY: Routledge, 2019), pp. 34-48.

${ }^{9}$ Vitalis, White World Order.
} 
white settler Australia? We contend that how the 'international' is understood, theorised, and discussed in different locations is also shaped by how the world looks from different vantage points.

Building on these insights, the project from which this Special Issue emerged is concerned with the following broad questions: How did IR as a field of study define itself as a self-contained body of knowledge that is distinct from other disciplines in different parts of the world? We know that the ideas of the 'international' travelled through both official - universities, think tanks, journals, and so on - as well as unofficial - private member groups, networks of individuals channels. So how did people, ideas, and institutions come together to form a distinct discipline? What were the issues, contestations, and epistemic concerns that shaped the institutionalisation of IR? Taken together, how do these different stories of what we generally see as a monolith, 'International Relations' hang together? What do they tell us about how IR as a discipline is understood and negotiated in different parts of the world? Contributions on the global state of the discipline, especially the edited volume by Arlene B. Tickner and Ole Wæver, has made a valuable contribution to how IR is practiced in different parts of the world. ${ }^{10}$ This Special Issue builds on this work by taking a more historical approach that focuses on the origins or births of IR in various locations.

This project is significant and timely for many different reasons. Dislocating the focus from IR's 'origins' in 1919 - at best, a very contested story - to its global transmission will help to analyse IR's agenda over the past one hundred years. These alternative histories will allow us to appreciate that the development of IR as a global discipline was only possible through a transnational circulation of key ideas such as sovereignty, empire, Commonwealth and, especially, competing notions of the 'international'. This might even provide us with new insights into the 1919 story. New disciplinary histories have argued that in the early IR debates about race and empire, the non-West was not just the centre of intellectual arguments about these matters, but it was also the physical location from where these arguments were being made. Finally, constructing a more inclusive history of the origins of IR advances the ongoing efforts towards decolonising the discipline. Framing our narratives around the metaphor of 'multiple births' allows for the possibility to situate the emergence of IR in its global context in the following ways:

First, what are the myriad ways in which the political and academic lives of the discipline intersect in different parts of the world? Unquestionably, several studies in recent years have painstakingly revealed to us the interconnectedness of imperialism and IR, for instance; but that is indeed using a broad brush to paint the whole discipline. Now that we have become attentive to the broad discursive space in which IR as a discipline was shaped, courtesy of the very fine work that has been done by the historians of the discipline, it is important to remember that the networks and the nodes of its operation beyond the United States and Western Europe remain largely unexplored. This project started out as an enquiry into the different roots of IR, outside of the US and Western Europe. But as the papers included in this Special Issue reinforce, the routes were as important as the roots themselves. Routes in the sense of both the borrowing of ideas from different disciplines as well as from different (primarily, Western) locations. The articles in this collection, while anchoring themselves in specific locations/roots, also constantly remind us of the several routes through which the ideas, institutions, and (disciplinary) identities travelled. This includes how mimicry, to assert the old postcolonial paradox, engenders novel formations.

\footnotetext{
${ }^{10}$ Arlene B. Tickner and Ole Wæver (eds), International Relations Scholarship Around the World (London, UK: Routledge, 2008). See also Hugh C. Dyer and Leon Mangasarian (eds), The Study of International Relations: The State of the Art (London, UK: Macmillan, 1989); Karen Smith, 'International Relations in South Africa: A case of "add Africa and stir"?', Politikon, 40:3 (2013), pp. 533-44; Olajide Aluko, 'The study of International Relations in Nigeria', Millennium: Journal of International Studies, 16:2 (1987), pp. 313-17; Xiaomin Huang, 'The invisible hand: Modern studies of International Relations in Japan, China, and Korea', Journal of International Relations and Development, 10 (2007), pp. 168-203; Siddharth Mallavarapu, 'Development of International Relations theory in India', International Studies, 46:1-2 (2009), pp. 165-83.
} 
Second, in its historiography, the discipline of IR is almost always tethered to Political Science. In the United States, IR is often seen as a subdiscipline of Political Science, while in the United Kingdom the discipline has historically detached itself from its parent discipline. Nonetheless, the focus largely remains on Political Science, although as the alleged tradition vs science 'second great debate' claims, the British tradition of political 'science' itself is one of historicism and philosophy rather than of acute scientism. ${ }^{11}$ Is that true of how the discipline came to be imagined elsewhere? Defining IR in terms of inclusion or exclusion from Political Science - the discipline that studies the state - presupposes an immersion in the vocabulary of the nation, and assumes that the territorial nation-state is the primary unit of analysis. However, territoriality has not always been the core idea of the nation. Segregationaist South Africa, for instance, viewed the state and the world beyond through a racialised, rather than a territorial, order. Is it any surprise then when, in 1928 the then Vice Chancellor of the University of Cape Town first wrote to Ivison Macadam about opening an Institute of International Affairs, he viewed it purely as an institute that would create expertise for solving the 'native problem'? Indeed, it was anthropology rather than politics that provided early competition to the fashioning of IR in the country. ${ }^{12}$ Or, in the case of Turkey, as Zeynep Gulsah Capan and Türkan Özge Onursal-Beşgü explain, ${ }^{13}$ international law was the natural parent discipline, given the state's constant tussle between international law and civilisational identity. Similarly, in Yih-Jye Hwang's article in this issue, international law was the primary route through which International Relations came to China.

Third, the broad question of how we define and narrate a 'discipline' becomes even more pertinent in the case of IR, which often struggles to retain a separate identity. Disciplinary identities are usually framed around themes of common acceptance and a community of knowledge. According to Immanuel Wallerstein, a discipline can mean one or all of the following three things. Firstly, as a field of enquiry, every discipline encompasses its own set of questions, relatively autonomous from other fields of enquiry. These questions can be eternal or contextual. Over time, a discipline develops its own sets of concepts and ideas that distinguish it from other fields. Secondly, as a community of scholarship, a discipline facilitates certain styles of scholarship and prioritises specific ways of understanding, accumulating, and disseminating knowledge. And thirdly, as institutional identities, disciplines help distinguish and sustain university departments, degree programmes, professional associations, and publication streams. ${ }^{14}$ In all of these formations, a discipline is neither entirely a project nor fully a process. Closer attention to disciplinary practices reveals the constraints that are outwardly imposed - funding processes, the skewed nature of the knowledge economy, among other things - but also map how disciplinary boundaries are enshrined and reinforced through self-referential mechanisms. As much as disciplinary histories are narrations of these practices, they also ought to reflect on their own role in an ordering discourse. Memories of the past, including the ones inscribed in official documents, are always partial. Disciplinary histories are, by default, complicit in the production of subjective memories as truth. The histories of discursive violations, disordering and fracture are as important for any discipline. Such counter-narratives allow the possibilities for disciplines to develop in dialogic, if not entirely dialectical, ways. They bring attention to the purpose of knowledge and the politics of its production, and allow for both democratisation as well as discursive plurality.

How do we build these counter-narratives? Where are the archives to be mined? And how do we understand and overcome the silences which, as Michel-Rolph Trouillot tells us, occur at each stage of historical production: (a) the moment facts are created, that is, the making of sources; (b)

\footnotetext{
${ }^{11}$ Hedley Bull, 'International theory: The case for a classical approach', World Politics, 18:3 (1966), pp. 361-77; Morton Kaplan, 'The new Great Debate: Traditionalism vs. science in International Relations', World Politics, 19:1 (1966), pp. 1-20.

${ }^{12}$ Thakur and Vale, South Africa, pp. 125-33.

${ }^{13}$ Zeynep Gulsah Capan and Türkan Özge Onursal-Beşgü, 'Debating the "International”: Turkey and the Formation of the Discipline of IR', paper presented at 'The Many Births of IR' Conference, University of Leiden, 16-17 May 2019.

${ }^{14}$ Immanuel Wallerstein, 'Anthropology, sociology, and other dubious disciplines', Current Anthropology, 44:4 (2003), pp. 453-60; Craig Calhoun, 'Comments [Response to Wallerstein]', Current Anthropology, 44:4 (2003), pp. 461-2.
} 
the moment that facts are assembled, that is, the making of archives; (c) the moment the facts are retrieved, that is, the making of narratives; and (d) the moment when they become retrospectively significant, that is, the making of history. ${ }^{15}$ Importantly, counter-narratives too have their own histories of skewed production, their operations of silencing, and their power stratagems that lead to continued disempowering of the unheard. While there are many possible pathways, our own approach in this collection is to narrate national histories of the discipline, albeit with an acknowledgement of the implicit dangers of reinforcing disciplinary nationalism. The only prevention against the canonisation of any perspective, Nigerian writer Chinua Achebe tells us, is to keep writing multiple stories. ${ }^{16}$ This Special Issue, which brings together perspectives from several different locations, is consequently an invitation to write more such histories.

While the initial idea was to gather together a larger group of regionally representative scholars, this was eventually not possible, for a number of reasons. While this Special Issue therefore includes a smaller number of articles than we had originally hoped, we believe that it achieves the aim of providing an insight into how the 'birth of IR' must be reconceptualised as the 'births of IR' to do justice to the many different ways in which the discipline made its appearance in parts of the world that are not the US, the UK, or Western Europe. Below follows a brief overview of the contributions, which cover China/Taiwan, Brazil, Korea, Ghana, and Australia. All contributors were asked to reflect on the following questions:

(a) What are the origin stories of IR in your country/region of specialisation?

(b) How was the discipline received and integrated into teaching, research, and policymaking in its formative years?

(c) To what extent did disciplinary narratives attempt to articulate the agency of the developing world?

(d) What are the implications of this rethinking of the history of the discipline for the study and practice of contemporary IR?

The objective of this exercise is not only to shed light on how diverse experiences have shaped the development of the discipline in different parts of the world, but also to showcase the many similarities, some of which will be outlined below. Importantly, however, we contend that similarities - whether with regard to influences, actors, motivations, or institutionalisation - must not be assumed to exist on the basis of Western universalist ideas, but can only be established based on empirical evidence and the writing of a more inclusive historical narrative about the origins of IR.

\section{The contributions: China/Taiwan, Brazil, Korea, Australia, and Ghana}

Yih-Jye Hwang's article explores how International Studies emerged and developed as a field of study in China from the late nineteenth century to the late twentieth century. In including the role of different intellectuals and experts, namely practitioners, translators, historians, legal scholars, and political theorists/scientists, he emphasises the multiple actors that played a role in the development of what would become Chinese IR. In particular, he is interested in how ideas of the international travelled to China in the late nineteenth and early twentieth centuries, and how ideas, concepts, and theories central to Western international thought, such as sovereignty and the modern international law, were transplanted to China. He also considers the impact of early development on the current state of the discipline in the PRC and Taiwan, highlighting some important differences. In particular, efforts to establish a distinct Chinese school of IR by Beijing are not shared in Taiwan, where Western IR is more readily accepted. In emphasising

\footnotetext{
${ }^{15}$ Michel-Rolph Trouillet, Silencing the Past: Power and the Production of History (Boston, MA: Beacon Press, 1995$)$, p. 26.

${ }^{16}$ Chinua Achebe, Hopes and Impediments: Selected Essays (New York, NY: Doubleday, 1990).
} 
how studies of International Relations were largely grounded in a problem-solving approach to various issues that China (and Taiwan) have faced, and how IR was perceived as instrumental, including aimed primarily at the training of government foreign affairs experts, Hwang reflects on how the rationale for developing and supporting the field of study was perhaps not as different to the motivations driving it in places like the United States.

Hwang's emphasis on the role of diplomatic thought and practice in the Qing Empire and the early Republic shows commonalities with Carlos Milani's article on the development of IR in Brazil. He too underlines the role of diplomat-intellectuals, and military officials, in the shaping of the discipline, specifically with regards to the strong influence of geopolitical thinking. In particular, Milani considers the significance of Brazil's nineteenth-century diplomatic thinking in shaping the country's conceptions of modernisation and sovereignty. He argues that the development of IR in Brazil was reflective of the tensions inherent in a national development project rooted in an external search for recognition, prestige, and autonomy, but at the same time beleaguered by high levels of domestic inequality. He further contends that accounts of the development of IR in Brazil cannot disconnect geopolitics, defence, and strategic studies from diplomacy, foreign policy, multilateral relations, and regional dynamics.

Jungmin Seo and Young Chul Cho lay out the paradox of IR in Korea: the enunciation of an autonomous 'Korean IR' has largely occurred through forming a subservient relationship with American IR on the one hand, and the Korean state on the other. This seemingly contradictory tendency, they argue, comes from the imbricated hierarchies of colonialism in Korean history. Colonised by a non-Western power from within the civilisational sphere, Japan, Koreans experienced a sense of humiliation that could only be addressed through purging all Japanese influence. Hence, unlike several other Western colonial contexts where postcolonial, non-Western scholarship challenged Western ideas, albeit at times through ingenious forms of mimicry, in Korea, American understandings of the world as well as modes of accumulation of knowledge were imported wholly and uncritically. This has meant, as the authors show, that even in the contemporary period, when influenced by the critical turn, Korean IR scholars critique western IR, these criticisms remain intended towards further entrenching Korea in the West, rather than distancing itself from it. This 'subliminal Westoxification' comes from the ways in which Korea's specific colonial history informs Korea's perception of self as well as its place in the world. The second strong influence on IR in Korea, they contend, comes from a strong statist tradition, once again informed by responses towards Japanese colonialism. In effect, they argue, IR scholarship in Korea is inseparable from statecraft.

Challenging the existing disciplinary history of the creation of IR in Australia as coinciding with the foundation of an IR chair at the Australian National University (ANU) in 1949, Alexander E. Davis highlights the politics of the epistemic group called The Round Table in establishing the Australian Institute of International Affairs. This was part of an imperial circulation of ideas that can be traced back to the emergence of the Union of South Africa in the late 1800s, and included the formation of Institutes of International Affairs in Great Britain, Australia, Canada, South Africa, New Zealand, and India. His exploration of the settler colonial nature of Australian IR focuses on the importance of racial ideologies and imperial networks. Throughout, he shows how colonial anxieties about settlement and invasion were key to how the 'international' was imagined in Australia, and how this subsequently impacted on the intellectual and institutional development of the field. In addition, the blurring of the international and the domestic - with indigenous people being regarded by early Australian IR as 'external' - was a constitutive element of the founding of IR. Noting that the control of territory by settlers is the foundational concern of the Australian state (based on the notion of terra nullius: that Australia was 'empty' and its land 'unutilised' and 'unsettled' prior to the arrival of the British in 1788) he argues that this shaped Australian identity and was foundational to its international thought and its politics. In addition, he shows how these ideas not only impacted on Australian IR, but also considers their implications for the discipline as a whole. While we might not regard issues around 
settlement and land tenure as belonging to the 'international' today, we cannot ignore the fact that colonial settlement was, for a long time, thought of as international affairs, and that the connection between land, sovereignty, and settlement remains foundational to the international system.

Finally, Thomas Kwasi Tieku's contribution on the Legon School of IR (LSIR) is not only significant in terms of understanding the development of IR in Ghana, but shows how it can be regarded as a precursor to decolonising IR scholarship, African IR, and the Global IR movement. In particular, the innovative ways in which LSIR scholars mix southern epistemologies, relational ontology, and anti-colonial perspectives with standard social sciences research techniques provide an insight into how IR can - and has - been done differently. Tieku also shows how, through its privileging of African agency, social justice, and Global South issues, including the search for a new and equitable international order, the Legon School rejected the Western version of IR that serves to maintain the existing international economic and political order. The establishment of the Legon School formed part of a broader attempt to dismantle the influence of British colonialism on university education in Ghana. These early attempts at decolonising knowledge in Africa are sometimes neglected in more contemporary debates about the need to decolonise the (IR) curriculum, both by students and IR scholars. The way in which the Legon School introduced students to IR was firmly decolonial, and emphasised collectivist ideas such as Pan-African solidarity and South-South cooperation. The significance of scholars returning to Ghana after having completed their studies abroad, particularly in Canada and the US, also speaks to the way in which ideas travelled and were subsequently introduced and modified. Relatedly, Tieku touches on how ideas originating in the structuralist tradition of economic development of postcolonial societies pioneered by Latin American scholars like Raúl Prebisch and Andre Gunder Frank made their way into IR scholarship in Ghana, emphasising the transfer of knowledge not just from North to South but also within the South in the development of IR in states of the Global South.

These contributions highlight or reinforce the following key insights. First, while an exchange of ideas between the North and the South (or the colonial powers and the colonies) had a significant impact on how the field developed, knowledge transfer within the southern hemisphere was equally important. Second, individuals, particularly practitioners - diplomats, government officials - have played a significant role in shaping the direction of the field. Third, similarities can be identified with regard to factors driving the development of the discipline - including instrumentalist motivations such as advancing the interests of the state - in different parts of the world, both North and South. Fourth, the contributions reveal that issues that are not currently considered as being part of IR (for example, race or settlement) were in many cases foundational to the development of the field. Indeed, a closer historical and transnational investigation challenges the existing, accepted narratives of disciplinary history. And finally, some of the current debates in IR (for example, about decolonising the discipline) are not new, and similar questions about how to do IR differently, and from a distinctly Global South perspective, have been asked (and answered) decades ago by scholars in places like Ghana. An important motivation behind uncovering these disciplinary histories is therefore that it will allow us to revisit these ideas, to recognise the contributions that have been made by scholars in the Global South but remain marginalised, and enable them to inform contemporary debates.

In conclusion, we invite readers to critically engage with the contributions to this Special Issue, which will inevitably draw them in some new directions and summon them to think about the discipline in its myriad entanglements. However, we also invite them to consider building on this work by interrogating and excavating the multitude of disciplinary histories that remain to be told. Finally, we hope that this collection of essays will contribute not only to helping us to construct a more inclusive disciplinary history beyond that told in standard IR texts, but also to a greater understanding and appreciation of how key processes that shape the practice of international relations elsewhere can tell us more about global politics as a whole. 
Acknowledgements. Many thanks to the editors and the reviewers for their helpful feedback on earlier drafts. We also gratefully acknowledge Leiden University's Institute for History, the Leiden University Fund, and the World International Studies Committee for providing funding for the workshop that resulted in this Special Issue. Most of all, our gratitude goes to all the participants of the workshop for their ideas and insights on disciplinary history.

Vineet Thakur is a Lecturer in International Relations at Leiden University. Author's email: v.thakur@hum.leidenuniv.nl

Karen Smith is a Lecturer in International Relations at Leiden University, and an Honorary Research Associate at the University of Cape Town. Author's email: k.smith@hum.leidenuniv.nl

Cite this article: Thakur, V., Smith, K. 2021. Introduction to the Special Issue: The multiple births of International Relations. Review of International Studies 47, 571-579. https://doi.org/10.1017/S0260210521000498 